\title{
Analysis of the Level of Road Damage Due to Vehicle Volume on Rigid Perkerasa on the Pantura Tegal - Pemalang Road in Tegal Regency
}

\author{
Wahidin \\ Faculty of Engineering, Universitas Muhadi Setiabudi (UMUS) Brebes, Indonesia \\ Email: wahidinnaures@gmail.com
}

How to Cite: Wahidin, W. (2019). Analysis of the Level of Road Damage Due to Vehicle Volume on Rigid Perkerasa on the Pantura Tegal - Pemalang Road in Tegal Regency. International Journal for Educational and Vocational Studies, 1(4), 364-367

\section{ARTICLE HISTORY}

Received: 10 May 2019

Revised: 13 June2019

Accepted: 12 July 2019

\section{KEYWORDS}

Road Damage;

Rigid Pavement;

Vehicle Volume;

\begin{abstract}
Traffic volume is one of the factors causing road damage. Rigid pavement is generally used on roads that have fairly heavy traffic. With the increasing number of vehicles it is possible that the road will suffer damage in a relatively short time. The purpose of this study was to determine the effect of the volume of vehicle types with the level of road damage and the relationship of the volume of vehicle types with the level of road damage on rigid pavement. So it can be predicted in advance the value of road damage that will occur. The method used in this research is the method of analyzing vehicle volume and the level of road damage using the regression method. Namely to get the function of the relationship with the value of $R^{2}$ (coefficient of determination) which shows the magnitude of the effect of changes in the variation of the volume of vehicle types to changes in the value of road damage. This research was conducted in the Pantura Tegal - Pemalang Lane section. There is a relationship between the volume of vehicle types and the value of road damage. With the result $R^{2}=0,892$ show $k$ of damage roads that influenced the volume type of light vehicles and heavy vehicles have a percentage of $89.2 \%$. With the results of the heavy vehicle equation $(X 2)$ and the value of road damage $(Y)$ that is $Y=0,27 X 2+8,887$. From this equation can be described as follows .. Regression coefficient $X 2(a)=0,27$, meaning that heavy vehicles by 100 vehicles / day will increase the level of road damage by 27 , constant $(c)=$ If no vehicles pass a road, the road will suffer a road damage of 8,887 .
\end{abstract}

This is an open access article under the CC-BY-SA license.

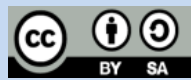

\section{INTRODUCTION}

Tegal Regency is a regency located in the northwestern part of Central Java Province. Tegal Regency has a strategic location on the road Semarang - Tegal - Cirebon, and Semarang - Tegal - Purwokerto and Cilacap. With this strategic location, Tegal Regency is crossed by the Pantura Main Line, and also has a main crossing from the north coast to the north coast. That makes Tegal Regency have started to develop in a number of industries and economies. With this development, the flow of vehicles, especially vehicles that have a large tonnage, will also increase. This causes many roads to be damaged because they exceed the load capacity of the previously constructed plan. The road network is also a land transportation infrastructure that plays a very important role in the transportation sector for the distribution of goods and services, so a good road pavement design is a must.

With the population increasing every year and the increasing number of vehicles, the need for road - transportation facilities is very large. Therefore, optimal road construction planning and technical requirements are needed . according to function, volume and nature of traffic so that the construction can be of maximum use for the development of the surrounding area. Road construction planning without adequate road maintenance, both routine and periodic, will be able to cause substantial damage to the road, so that the road will lose its function faster. Road damage that occurs in various regions today is a very complex problem and the losses suffered are really big, especially for road users, such as the occurrence of long travel times, congestion, traffic accidents, and others. These individual losses will be the accumulation of global economic losses for the area .

Basically the road will experience a decrease in its structural function in accordance with increasing age. Roads are currently experiencing damage in a relatively very short time (early damage) both newly built roads and newly restored roads (overlay). 
Cement concrete road or rigid pavement consists of slabs and concrete foundation layers. Pavement is generally used on roads that have fairly heavy traffic, with the increasing number of vehicles it is possible that the road will suffer damage in a relatively short time. But if the rigid pavement is maintained properly and remains in good condition then the cement concrete road will have a longer life. But once this cement concrete road is damaged, the damage will take place very quickly. Therefore it is very important to carry out preventative maintenance. Assuming the background above, I took the title of this thesis writing, "Analysis of the Level of Road Damage Due to the Volume of the Vehicle on Rigid Pavement in the Tegal - Pemalang Pantura Line".

\section{METHOD}

Meto de research is the work demands that they meet the objectives of research studies that have been determined. Another understanding of methodology is a process, principles, procedures in approaching problems and efforts to find answers. Methodology can also be interpreted as a systematic study in a qualitative or quantitative manner with various methods and techniques. This method can be in the form of scientific analysis, namely qualitative descriptive analysis and quantitative analysis.

According to Sugiyono (2010) explains that research methods are scientific ways to obtain valid data, with the aim to be found, developed and proven, a certain knowledge so that in turn it can be used to understand, solve, and anticipate problems. The research method is basically a scientific way to collect data with specific purposes and uses. The scientific way means that research activities are based on scientific characteristics, namely rational, empirical and systematic.

1. Data source

a. Primary data

Traffic Volume Data. This data is taken only during peak hours, based on vehicle volume data from the Tegal city transportation office. Because the initial traffic volume data is obtained through secondary data (MKJI: 1997).

b. Road Damage Data

This data is taken by measuring and calculating the level of damage to the road under study.

2. Secondary Data

a. Road Inventory Data

This data was obtained from the Tegal Regency Bina Marga Office. Data needed includes the length and width of the road, the number of sections, the median, the number of lane roads and completeness. b. Traffic Volume Data

Traffic volume data was obtained from the Tegal Regency Transportation Office. This data includes data on the volume of vehicles passing the road per hour. This data is not used for research analysis but rather is used as a reference for primary data collection that is carried out in peak hours (MKJI: 1997).

\section{Analysis Method}

The analytical method used is:

a. Method of analysis of vehicle volume and value of Damage in general.

b. Regression analysis method to get the relationship pattern of vehicle volume with the level of road damage

\section{RESULTS AND DISCUSSION}

1. V olume ago Linta

Each type of vehicle has different characteristics because of the dimensions, speed, acceleration and maneuverability of each type of vehicle. To find the impact of the required space requirements it is usually stated in passenger car units (smp), while to look for damage to the pavement structure it is usually stated with the Vehicle Damaging Facktor (VDF) which is usually calculated by:

\section{(Load of a single axis in $\mathrm{Kg})^{4}$}

(Single axis)

8160

$(\text { Load of a single axis in } \mathrm{Kg})^{4}$

$($ Single axis $)=0.086$

8160

And the magnitude of emp vehicles is in accordance with MKJI (1997) for roads outside the city in flat alignment type. In the traffic survey using vehicles / hours in accordance with the types of vehicles that have been classified as heavy vehicles (trucks, large buses), light vehicles (cars, pick ups, small buses, small trucks), motorcycles and vehicles not motorized. Vehicle volume data on each section can be seen in table 1 below. 
Table 1. Volume of Vehicle Type (vehicle /day)

\begin{tabular}{|c|c|c|c|c|c|c|}
\hline \multirow[b]{2}{*}{ No } & Name & \multirow[b]{2}{*}{ Pathway } & Vehicle & Vehicle & Bike & Vehicle \\
\hline & Street & & $\begin{array}{l}\text { Light } \\
\text { (kend / day) }\end{array}$ & $\begin{array}{c}\text { Weight } \\
\text { (kend / day) }\end{array}$ & $\begin{array}{l}\text { Motorcycle } \\
\text { (kend / day) }\end{array}$ & $\begin{array}{l}\text { No Motorized } \\
\text { (kend / day) }\end{array}$ \\
\hline \multirow[t]{3}{*}{1} & Highway & Direction & & & & \\
\hline & Dampyak & West East & 2916 & 339 & 13261 & 29 \\
\hline & & $\begin{array}{l}\text { Direction } \\
\text { East West }\end{array}$ & 3168 & 442 & 11067 & 38 \\
\hline \multirow[t]{3}{*}{2} & Highway & Direction & & & & \\
\hline & Suradadi & West East & 4016 & 456 & 10379 & 31 \\
\hline & & $\begin{array}{c}\text { Direction } \\
\text { East West }\end{array}$ & 1663 & 314 & 12912 & 27 \\
\hline \multirow[t]{3}{*}{3} & Highway & Direction & & & & \\
\hline & Kramat & West East & 4183 & 281 & 12824 & 12 \\
\hline & & $\begin{array}{c}\text { Direction } \\
\text { East West }\end{array}$ & 2737 & 214 & 7079 & 9 \\
\hline
\end{tabular}

From this data the traffic volume for each road segment is different for each type of vehicle

2. Road damage value

Damage that occurred in each of the roads studied was different - different. Of the various types of damage to the road can be found the value of the damage. Damage value

$(\mathrm{Nr})$. is obtained from the total amount and damage value per each type of damage

$(\mathrm{Nq})$. The assessment of surface conditions first looks for the value of the percentage of damage

$(\mathrm{Np})$. To find the $\mathrm{Np}$ value by:

Number of Road Damage Segments

$\mathrm{Np}=\frac{\text { Number of Roads }}{\mathrm{N}} \mathrm{N} 00 \%$

Table 2. Percentage values of road damage

\begin{tabular}{ccc}
\hline Percentage & Category & Value \\
\hline$<5 \%$ & So little & 2 \\
\hline $5 \%-20 \%$ & a little & 3 \\
\hline $20 \%-40 \%$ & Is & 5 \\
\hline$>40 \%$ & Many & 7 \\
\hline
\end{tabular}

After $\mathrm{Np}$ is obtained to find the damage value $(\mathrm{Nq})$, it remains to be multiplied by the value of the amount of damage $(\mathrm{Nj})$. For the $\mathrm{Nj}$ value itself, there is a choice of values based on the type of damage available, the following values are:

Table 3. Value of type of damage

\begin{tabular}{cc}
\hline Type of Damage & Value \\
\hline Asphalt concrete & 2 \\
\hline Penetration & 3 \\
\hline Patch & 4 \\
\hline Cracked & 5 \\
\hline Free & 5.5 \\
\hline Hole & 6 \\
\hline Plot & 6 \\
\hline Wave & 6.6 \\
\hline Disappear & 7 \\
\hline Hemisphere & 7 \\
\hline
\end{tabular}

If the value of $\mathrm{Np}$ and the value of $\mathrm{Nj}$ have been multiplied, then the value can be used to find the value of the amount of road damage $(\mathrm{Nq})$. The method can be classified in the following table.

Table 4. Percentage values for total road damage

\begin{tabular}{cccccc}
\hline \multirow{2}{*}{ No. } & \multirow{2}{*}{ Type of Damage } & \multicolumn{4}{c}{ Percentage of Value Outside the Damage Area } \\
\cline { 3 - 6 } & & $\leq 5 \%$ & $5 \%-20 \%$ & $21 \%-40 \%$ & $\geq 40 \%$ \\
\cline { 3 - 6 } & & So little & a little & Is & Many \\
\hline 1 & Asphalt concrete & 4 & & & \\
\hline 2 & Penetration & 6 & & & \\
\hline 3 & Patch & 8 & 12 & 20 & 28 \\
\hline 4 & Cracked & 10 & 15 & 25 & 35 \\
\hline 5 & Free & 11 & 16.5 & 27.5 & 38.5 \\
\hline 6 & Hole & 12 & 18 & 30 & 42 \\
\hline 7 & Plot & 12 & 18 & 30 & 42 \\
\hline 8 & Wave & 13 & 19.5 & 32.5 & 45.5 \\
\hline 9 & Disappear & 17 & 21 & 35 & 49 \\
\hline 10 & Be land & 14 & 21 & 35 & 49 \\
\hline
\end{tabular}

The value of the amount of damage has been obtained so all that remains is added to each type of damage and can be obtained from the damage value $(\mathrm{Nr})$. Because the formula for finding the value of $\mathrm{Nr}$ itself is the total number of $\mathrm{Nq}$.

3. Relationship of Light Vehicle Volume, Heavy Vehicle, Motorcycle, Non Motorized Vehicle and Damage Value

The research result kendaraa volume $\mathrm{n}$ and the value of the damage was analyzed by non-linear regression. The variables used are the types of vehicles that are grouped into light vehicles as variable $\mathrm{X} 1$, heavy vehicles as variable $\mathrm{X} 2$, motorcycles as variable $\mathrm{X} 3$, non-motorized vehicles as variable $\mathrm{X} 4$ and value of road damage as variable Y. Analysis was performed using the SPSS application. Recapitulation of X1, X2, X3, X4 and Y can be seen in the following table. 
Table 4.17 Recapitulation of variables Z1, X2, X3, X4, and Y

\begin{tabular}{|c|c|c|c|c|c|c|c|}
\hline NO & Street Name & Pathway & $\begin{array}{c}\text { Value } \\
\text { Damage } \\
\text { Road (Nr) } \\
(\mathrm{Y})\end{array}$ & $\begin{array}{c}\text { Vehicle } \\
\text { Light } \\
\text { (kend / day) } \\
\text { (X1) } \\
\end{array}$ & $\begin{array}{c}\text { Vehicle } \\
\text { Weight } \\
\text { (kend / day) } \\
\text { (X2) }\end{array}$ & $\begin{array}{c}\text { Bike } \\
\text { Motorcycle } \\
\text { (kend / day) } \\
(\mathrm{X} 3) \\
\end{array}$ & $\begin{array}{c}\text { Vehicle } \\
\text { No motorized } \\
\text { (kend / day) } \\
(X 4)\end{array}$ \\
\hline \multirow[t]{2}{*}{1} & Highway & West East & 55 & 2916 & 339 & 13261 & 29 \\
\hline & Dampyak & East West & 55 & 3168 & 442 & 11067 & 38 \\
\hline \multirow[t]{2}{*}{2} & Highway & West East & 69 & 4016 & 456 & 10379 & 31 \\
\hline & Suradadi & East West & 41 & 1663 & 314 & 12912 & 27 \\
\hline \multirow[t]{2}{*}{3} & Highway & West East & 33 & 4183 & 281 & 12824 & 12 \\
\hline & Kramat & East West & 33 & 2737 & 214 & 7079 & 9 \\
\hline
\end{tabular}

From the results of the analysis show the type of vehicle is quite influential on road damage. $\mathrm{R} 2$ is indicated by the results of determination coefficient of $89,2 \%$. This indicates that the type of vehicle and affect the level of damage to roads amounted to $89,2 \%$.

Regression analysis was carried out to get the results of the heavy vehicle equation (X2) and the value of road damage (Y), namely $\mathrm{Y}=0,27 \mathrm{X} 2+8,887$. From this equation can be described as follows. Regression coefficient $\mathrm{X} 2(\mathrm{a})=0,27$, meaning that a heavy vehicle of 100 vehicles / day will increase the level of road damage by 27 , constant (c) = If no vehicle crosses a road, the road will experience road damage of 8,887 .

\section{CONCLUSION}

There is a relationship between the volume of vehicle types and the value of road damage. With the results $R^{2}=0,892$ with the results of the equation of heavy vehicles (X2) and the value of road damage $(\mathrm{Y})$ is $\mathrm{Y}=0,27 \mathrm{X} 2+8,887$. From this equation can be described as follows.

Coefficient X2 ( a ) = 0, 27, meaning that a heavy vehicle of 100 vehicles / day will increase the level of road damage by 27 , constant $(\mathrm{c})=$ If no vehicle crosses a road, the road will experience road damage of 8,887 . The pattern of the relationship is a $\mathrm{k}$ of damage path that influenced the volume type of light vehicles and heavy vehicles have a percentage of $89,2 \%$.

\section{REFERENCES}

Antoro, D., H, (2006). Analysis of the Accident Relationship and V/C Ratio (Case Study: Jakarta Cikampek Toll Road). Semarang: Diponegoro University Thesis

Ari, S. (2013). Pavement Concrete Road Pavement (Rigid Pavement)

Arifin, M., S. (2010). Comparison of flexible pavement and rigid pavement to traffic operational load with the AASHTO method on the roads of you sta $0+00-5+$ 350 Surabaya. Surabaya: National Development University

Department of Settlement and Regional Infrastructure, (2002). Flexible Pavement Planning Guidelines

Department of Settlement and Regional Infrastructure, (2003). Pavement Concrete Pavement Planning.
Department of Settlement and Regional Infrastructure, (2004). Manual Traffic Enumeration Survey .

Directorate General of Highways, (1990). Guidelines for Determination of Function Classification Roads in Urban Areas, Public Works Office, Jakarta .

Directorate General of Highways, (1991). Procedures for Pavement Maintenance

Directorate of Highways, (1987). Planning Thickness of Pavement Pavement Thickness

with Component Analysis Method Kaku (Rigid Pavement), Public Works Office, Jakarta

Khisty, C. Jotin. and B. Kent Lall, (2005). Basic - Basic Transportation Engineering. Jakarta: Erlangga.

MKJI.,(1997). Indonesian Road Capacity Manual. Jakarta: Bina Marga

Nugroho, A., (2012). Analysis of the effect of vehicle speed on the age of the road plan using analytical methods (case study of the Rembang Bulu road section). Surakarta: Thesis of Muhammadiyah University of Surakarta.

Public Works Department, (2007). General Specifications for Roads and Bridges.

Sukirman, S. (1993). Pavement Flexural Highway

Sugiyono, (2010). Qualitative and R\&D Quantitative Research Methods. CV Alfabeta. Bandung.

Sukirman , S. (1999). Pavement Jalan Raya, NOVA Publisher, Bandung.

Sukirman , S. (2003). CHAPTER II Pavement Highway, NOVA Publisher, Bandung.

Suryawan, A, (2009). Rigid Pavement Pavement . Offset Beta. Yogyakarta .

Tamin, Ofyar Z. (2000). Transportation planning and modeling . Bandung : ITB.

Wartadinata PW, and Situmorang RA. (2012). Analysis of Road Performance and Flexible Pavement Due to Overloading. Journal of Civil Engineering . Diponegoro University. Semarang.

Wikipedia. (2012). Road Capacity.

http://en.wikibooks.org/wiki/Management_Lalu_Linta/ Capacity_street.

Downloaded at 28/1 0/201 8 at 19:20

Zahra, (2011). Pavement Road. Article . Gunadarma University. Depok. 